\title{
Host preference fruit flies Bactrocera carambolae (Drew \& Hancock) and Bactrocera dorsalis (Drew and Hancock) (Diptera: Tephritidae)
}

\author{
Preferensi inang lalat buah Bactrocera carambolae (Drew \& Hancock) \\ dan Bactrocera dorsalis (Drew \& Hancock) (Diptera: Tephritidae) \\ Dodin Koswanudin $^{1,2}$, Adi Basukriadi² ${ }^{2}$ Made Samudra ${ }^{1}$, Rosichon Ubaidillah ${ }^{3}$ \\ ${ }^{1}$ Balai Besar Penelitian Bioteknologi dan Sumberdaya Genetik Pertanian \\ Jalan Tentara Pelajar Cimanggu, Kampus Penelitian Pertanian No.3A, Bogor 16111 \\ ${ }^{2}$ Departemen Biologi, Fakultas Matematika dan Ilmu Pengetahuan Alam, Universitas Indonesia \\ Kampus FMIPA UI, Gedung E Lt.2, Depok 16424 \\ ${ }^{3}$ Pusat Penelitian Biologi, Lembaga Ilmu Pengetahuan Indonesia \\ Jalan Raya Jakarta-Bogor Km. 46, Cibinong-Bogor 16911
}

(diterima Juni 2015, disetujui Maret 2018)

\begin{abstract}
Host plant preference amongst several fruit species was studied for two fruit fly species i.e. Bactrocera carambolae (Drew \& Hancock) and Bactrocera dorsalis (Drew \& Hancock), which both belong to $B$. dorsalis species complex. Both fruit fly species are known to be polyphagous and cause significant economic losses as pests of fruit crops. The aim of this research was to assess the host range of these major pests in Indonesia. The research was conducted at the Entomology Laboratory and Insect Specimen Collection Laboratory, Indonesian Center for Agriculture Biotechnology and Genetic Resource Research and Development, Bogor, West Java, Indonesia from June 2011 to March 2012. Comparative host preference for both species was studied with regard to malaya varieties of star fruit (Averrhoa carambolae), manalagi varieties of mango (Mangifera indica), guava aka water apple (Psidium guajava), citra water guava (Eugenia aquae), jamaica bol guava (Eugenia malaccenensis), and california papaya (Carica papaya). Our results suggest the strongest preference for malaya star fruit by $B$. carambolae followed by manalagi mango; and for california papaya followed by manalagi mango by $B$. dorsalis. The study also found that welahan variety star fruit is least preferred by both species of fruit fly.
\end{abstract}

Key words: Bactrocera carambolae, Bactrocera dorsalis, development, preference

\begin{abstract}
ABSTRAK
Lalat buah Bactrocera carambolae (Drew \& Hancock) dan Bactrocera dorsalis (Drew \& Hancock) dilaporkan dapat hidup dan berkembang pada berbagai jenis buah-buahan sehingga menimbulkan kerusakan pada buah yang sekaligus menimbulkan kerugian secara ekonomi. Penelitian ini bertujuan untuk mempelajari preferensi dan perkembangan $B$. carambolae dan $B$. dorsalis pada beberapa jenis buah dan untuk mendapatkan informasi jenis buah yang paling disukai lalat buah. Penelitian dilakukan di Laboratorium Entomologi dan Laboratorium Koleksi Spesimen Serangga, Balai Besar Penelitian dan Pengembangan Bioteknologi dan Sumber Daya Genetik Pertanian Bogor, pada bulan
\end{abstract}

\footnotetext{
*Penulis korespondensi: Dodin Koswanudin. Balai Besar Penelitian Bioteknologi dan Sumberdaya Genetik Pertanian 
Juni 2011 sampai Maret 2012. Perlakuan buah terdiri belimbing malaya (Averrhoa carambolae), mangga varietas manalagi (Mangifera indica), jambu biji getas merah (Psidium guajava), jambu air varietas citra (Eugenia aquae), jambu bol jamaika (Eugenia malaccenensis), dan pepaya california (Carica papaya). Hasil penelitian menunjukkan bahwa lalat buah B. carambolae paling tertarik pada buah belimbing malaya dan manggga manalagi dan $B$. dorsalis pada buah pepaya california dan mangga manalagi.

Kata kunci: Bactrocera carambolae, Bactrocera dorsalis, perkembangan, preferensi

\section{INTRODUCTION}

Fruit flies of the Bactrocera dorsalis (Drew \& Hancock) complex (Diptera: Tephritidae) currently cause the most economic damage to fruit and vegetable crops both directly and indirectly on a worldwide scale (Clarke et al. 2005). In Australia, fruit flies have caused economic losses reaching 4.6 billion AUS\$ (Plant Health Australia 2016). As a pest, fruit flies directly damage fruit as it develops on the tree, and continue to cause additional damage in fruit shipments during transportation (Drew 1997). Pests are commonly transported to new locations through fruit trade, and then become exotic pest species in the destination environments (Hardy 1977). As these problems often result from import and export activities, it is essential to ensure that traded produce are free from fruit fly infestation. In order to prevent the spread of Bactrocera carambolae-complex insects via the import or export of infested fruit, we need to know which fruit species are most preferred by the fruit flies as hosts.

Past research indicated that members of the Bactrocera complex prefer the fruit Families Anacardiaceae, Annonaceae, Clusiaceae, Moraceae, Myrtaceae, Rutaceae, Sapotaceae, and Solanaceae. Three fruit fly species complexes are polyphagous, including $B$. dorsalis whose larvae are hosted by 209 species from 51 plant families; B. papayae, hosted by 124 species of fruit within 42 plant families; and Bactrocera carambolae Drew \& Hancock with 77 host species, from 27 plants families (Drew 1997).

Fruit flies from B. carambolae and B. dorsalis are especially drawn to fleshy fruit types e.g. Star fruit, mango, guava, Psidium guajava, Eugenia aquae, papaya, citrus (Siwi et al. 2006; Widayana \& Kuswadi 2006; White \& Harris 1992). Fruit flies need sufficient food resources to sustain life and support reproduction throughout their lifecycle. Fruit plants are preferred hosts for fruit fly development (Chang et al. 2003; Sarwono 2000) for several reasons. They contain important nutritional resources, such as high water content for metabolism; sugars from nectar and honey used to fuel locomotion and flight, protein needed to attain sexual maturity; and protein with lipids to produce eggs (Nasution \& Kuswadi 2004; Fletcher 1987). Protein found in fruit is derived from nutrition sources readily available within the environment, (e.g. soil), whereas water content is drawn from from vapor and rain (Meats et al. 2004). Adult flies select host plants not only on the basis of nutritive value; they also seek out phenyl propanoids, such as methyl eugenol and ketones, which are produced by some plants. Phenylproponoids are organic compounds that play a part in plant tissue structure, and which can function to protect plants against UV light, pathogens and predators; or to provide color and scents that influence pollinators. Phenylproponoids derived from phenylalanine and or tyrosine are among the common of all secondary metabolites in plants, bacteria, and fungi. Fruit fly host selection reflects preference for the above nutrients and propanoids, which are signaled by fruit characteristics such as color, smell, taste, and texture (Shelly 2000; Shelly \& Kaneshiro 1991). In addition to physical traits, chemical characteristics in host plants may also influence host preference, and the subsequent development and biology of insects (Kostal 1993). The insect's preference on the host plants can effect the development, life table, and regeneration of a given insect (Singer 1986; Renwick 1989) and can determine their behavior. The host plant preferences of fruit fly species must be studied and observed in order to inform and enable pest management in the field (Han \& McPheron 1997). In this study, we examine the host preferences of 
B. carambolae and B. dorsalis for various fruit species and varieties, and study the effect of host preference on these pest species' development, life history, and behavior.

\section{MATERIALS AND METHODS}

\section{Collection duration and sites}

This research was conducted from June 2011 to March 2012 at the Entomology Laboratory of the Indonesian Center for Agricultural Biotechnology and Genetic Resource Research and Development, Bogor, West Java.

The $B$. carambolae and B. dorsalis individuals used for this study were collected at Mekarsari Garden, a national non-profit research center for fruit conservation, from plantations of star fruit (Averrhoa carambolae), mango fruit manalagi variety (Mangifera indica), guava fruit getas merah variety (Psidium guajava), water guava fruit citra variety (Eugenia aquae), jamaika malay apple fruit (Eugenia malaccenensis), and papaya california variety (Carica papaya). These fruit are for the most part commonly cultivated in Indonesia. Sample insects were also collected from mango that is cultivated in Indramayu. Both sites are located in West Java Province in Indonesia.

\section{Mass rearing of tested insects}

Insects studied in this research were sampled and collected from infested fruit trees and plants located in Mekarsari Garden, Bogor, and in mango orchards in Jatibarang, Indramayu, both located in West Java Province. The sampled fruit flies were identified to species level, and fruit flies from $B$. carambolae and $B$. dorsalis complexes were then reared, and 100 sampled adults were allowed to propagate. Infested fruit were stored in soft mesh cages, $50 \mathrm{~cm} \times 50 \mathrm{~cm} \times 25 \mathrm{~cm}$ in size, using sawdust laid at a thickness of $6 \mathrm{~cm}$ as pupation medium. The cages were located in a laboratory $6 \mathrm{~m} \times 5 \mathrm{~m}$ in size, kept at a constant temperature of $28{ }^{\circ} \mathrm{C}$, $70-80 \%$ in relative humidity and sufficient light for fruit fly propagation. The sawdust pupation medium was sifted weekly to separate and obtain the formed pupae. All pupae were transferred to sponges in petri dishes, within cloth mesh cages 40 $\mathrm{cm}$ x $40 \mathrm{~cm}$ x $40 \mathrm{~cm}$ in size. When these sampled insects reached the imago stage we increased the moisture of the sponges and added to each petri dish a piece of cotton soaked in a compound of protein hydrosilate, and granular sugar $(1: 4)$. We also added cotton soaked in honey solution (10\%) (Aluja et al. 1996; Vargas et al. 2000; Hasyim et al. 2006). Within 10 days of reaching imago stage, the collected fruit flies had matured and laid eggs. On day 10, eggs were harvested from the petri dishes using a lobed-tube $1 \mathrm{~mm}$ in diameter, and were placed on a prepared food medium, using a water drop pipet. The food medium consisted--per $\mathrm{kg}$--of $233 \mathrm{~g}$ wheat bran, $0.79 \mathrm{~g}$ nipagin $\mathrm{g}, 0.79 \mathrm{~g}$ sodium benzoate, $28 \mathrm{~g}$ bread yeast, $650 \mathrm{ml}$ water, $91 \mathrm{~g}$ granular sugar, and sufficient $\mathrm{HCl}$ to achieve acidity $(\mathrm{pH})$ of 4 . Each $1 \mathrm{~kg}$ of prepared food was used to incubate $1 \mathrm{ml}$ of fruit flies eggs (Resilva et al. 2007; Sikumbang 2005). The resulting pupae were placed in sand pupation medium. After incubation, the resulting $2^{\text {nd }}$ generation pupae were harvested by sifting them from the sand medium using soft mesh, and placing the intercepted pupae individually in petri dishes, following the same procedure as described above for the first generation pupae. The emerged adult flies were then collected and placed into a separate mesh cage for breeding. The entire process was repeated for multiple generations of continuous breeding, in order to obtain sufficient population numbers for research needs.

\section{Host fruit preferences of $\boldsymbol{B}$. carambolae and $\boldsymbol{B}$. dorsalis}

A colony of 450-500 pairs of male and female fruit flies from B. carambolae, and a similar sized colony from $B$. dorsalis species, were each placed in separate $50 \mathrm{~cm}^{3}$ mesh cages (one cage for each colony). Methyl eugenol was introduced to the cages to incite male flies to initiate copulation. A total of 90-100 inseminated (post-copulation) female fruit flies were placed into plastic jars $30 \mathrm{~cm}$ in height and $30 \mathrm{~cm}$ in diameter. Smaller jars (17 cm height and $16 \mathrm{~cm}$ diameter) containing host fruit were placed inside the large jars with the female fruit flies. Plastic pipes $1.5 \mathrm{~cm}$ long and $1 \mathrm{~cm}$ in diameter were connected to the smaller jars, creating an opening that would allow the scent of the fruit to escape into the larger jars, and the female fruit flies to enter the smaller jars. This 


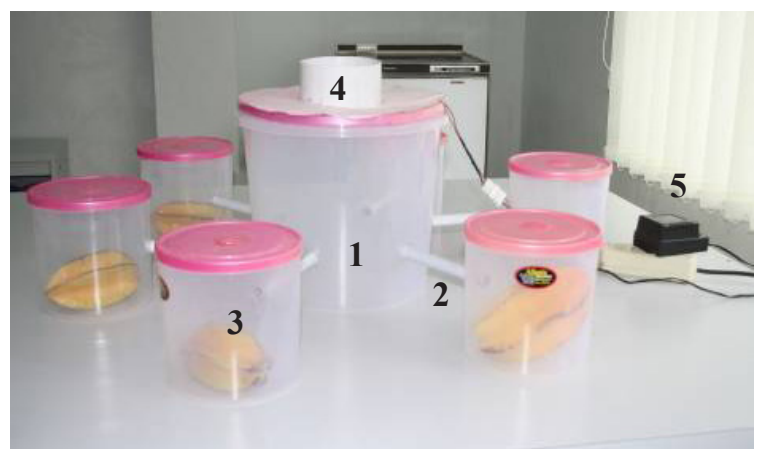

Figure 1. Wind tunnel front view. 1: fruit flies cage; 2: air canal pipe; 3: host fruit jar; 4: exhaust van; 5: adaptor.

entire apparatus of jars was contained within the $50 \mathrm{~cm}^{3}$ mesh cages. At the top of the mesh cages electrical exhaust fans were used to circulate the fruit scent from smaller to the larger jars in order to induce the female fruit flies to enter into the host fruit jars (Figure 1).

There are 2 variables in this research: the species of fruit fly (2 species), and the species of host fruits (6 species of fruit). The experiment was prepared using a complete randomized design with 5 replications of each treatment, for each fruit fly species $B$. carambolae and $B$. dorsalis. The treatments consisted of fruit fly exposure to fruit species $A$. carambolae, $M$. indica, P. guajava, E. aquae, E. malaccenensis, and C. papaya. The experimental treatments for $B$. carambolae and $B$. dorsalis were conducted separately, at different times. The parameters measured included number of fruit flies infesting the host fruit, number of eggs deposited in host fruit, number of deposited eggs reaching pupae stage, percentage of resulting pupae on fruit, and sex ratio of surviving pupae when they reach adulthood. The aim of this research is to identify which host fruit species are most preferred by the selected fruit fly species for oviposition, and are the best food source for the developing eggs/pupae.

\section{Analysis of data}

Oviposition preference and developmental data of fruit flies B. carambolae and B. dorsalis were analyzed using analysis of variance (ANOVA) and if significant were analyzed using the least significant difference (LSD) test at level 5\%.

\section{RESULTS}

Based on the analysis, the oviposition $B$. carambolae and $B$. dorsalis when provided different fruits species showed that $B$. carambolae was most attracted to star fruit (A. carambolae) for oviposition, whereas $B$. dorsalis was most attracted to papaya (C. papayae). An average number of 41.5 B. carambolae flies entered jars containing star fruits whereas only an average of 2.3 flies of this species entered the jars containing C. papayae. The reverse was true for flies of $B$. dorsalis species, 40.5 of which entered jars containing $C$. papayae, on average. $B$. dorsalis was least attracted to $E$. aquae (water guava citra) with only an average of 6.0 flies entering those jars (Table 1). These results correlate with the highest number of measured ovipositor injection sites found for each fruit fly species. Star fruits were found to have the most $B$. carambolae oviposition injection points, averaging 70.0; while $B$. dorsalis injection sites were highest in papaya fruit, numbering 73.0 points in average (Table 1).

These preferences were continued with regard to oviposition. B. carambolae preferred star fruit for oviposition, laying the greatest number of eggs (an average of 173.8) on that fruit species, while the highest average number of $B$. dorsalis eggs (180.3) were deposited on papaya fruit. (Table 2).

When the eggs developed into pupa, researchers found the greatest numbers of $B$. carambolae pupa in star fruit and the lowest numbers in papaya fruit, averaging 49.5 and 10.5 individuals, respectively (Table 3). This pattern was reversed for B. dorsalis pupae, which were found in greatest number in papaya and lowest number in A. carambolae species (36.5 flies and 11.0 flies, respectively) 
(Table 4). Our results also showed a correlation between the number of emerged pupae and the number of eggs deposited. The more eggs laid, the more larvae emerged. For both fruit fly species the proportion of eggs that succesfully emerged as pupae ranged from $60-80 \%$. Among all fruit, tested, $B$. carambolae the number of pupae was significantly higher in the star fruit sample, and the number of $B$. dorsalis pupae was significantly higher in papayae.

The proportion of $B$. carambolae pupae successfully reaching adulthood was highest for the population reared with star fruit and lowest for populations reared with water guava citra $(E$. aquae) $(90.4 \%$ and $57.4 \%$, respectively) (Table 5 ), whereas the success rate of $B$. dorsalis pupae in reaching adulthood was highest $(86.0 \%)$ in the populations reared using papaya and lowest $(57.9 \%)$ in those reared with star fruit (Table 6). It seems that each species has a preferred host fruit, and that availability of preferred fruit positively effects population development and growth.

Sex ratio observations of adult reared fruit flies revealed a higher proportion of females vs. males for both B. carambolae and B. dorsalis, for all plants tested. higher than male in the overall tested host plants (Table 3 and 4).

\section{DISCUSSION}

Reared populations of fruit fly species $B$. carambolae and B. dorsalis both showed marked (but different) preferences for fruit host plant

Table 1. Preferece of Bactrocera carambolae and Bactrocera dorsalis for fruit hosts in the laboratory

\begin{tabular}{lccccc}
\hline & \multicolumn{2}{c}{ B. carambolae } & & \multicolumn{2}{c}{ B. dorsalis } \\
\cline { 2 - 3 } \cline { 5 - 6 } Host fruit & Imago numbers & $\begin{array}{c}\text { Fruits infested } \\
\text { (point) }\end{array}$ & & $\begin{array}{c}\text { Imago numbers } \\
\text { (point) }\end{array}$ & $\begin{array}{c}\text { Fruits infested } \\
\text { (point) }\end{array}$ \\
\hline Averrhoa carambolae & $41.5+0.6 \mathrm{a}$ & $70.0+1.8 \mathrm{a}$ & & $6.0+0.4 \mathrm{c}$ & $10.5+0.3 \mathrm{~d}$ \\
Mangifera indica & $15.0+0.4 \mathrm{c}$ & $30.5+0.4 \mathrm{c}$ & & $32.3+1.0 \mathrm{~b}$ & $48.3+0.8 \mathrm{~b}$ \\
Psidium guajava & $17.0+0.4 \mathrm{~b}$ & $39.0+0.6 \mathrm{~b}$ & & $8.0+0.8 \mathrm{c}$ & $16.0+0.4 \mathrm{c}$ \\
Eugenia aquae & $11.5+0.3 \mathrm{~d}$ & $23.8+0.4 \mathrm{~d}$ & & $6.0+0.4 \mathrm{c}$ & $14.3+0.4 \mathrm{c}$ \\
Eugenia malaccenensis & $12.8+0.8 \mathrm{~d}$ & $32.5+0.9 \mathrm{c}$ & & $7.3+0.7 \mathrm{c}$ & $14.8+0.4 \mathrm{c}$ \\
Carica papayae & $2.3+0.4 \mathrm{e}$ & $11.5+1.2 \mathrm{e}$ & & $40.5+0.8 \mathrm{a}$ & $73.0+1.5 \mathrm{a}$ \\
\hline
\end{tabular}

Numbers in one column followed by the same letters are no significantly difference based on LSD test in level $5 \%$.

Table 2. Eggs laid by Bactrocera carambolae and Bactrocera dorsalis in fruit hosts

\begin{tabular}{lcc}
\hline \multirow{2}{*}{ Host fruit } & \multicolumn{2}{c}{ Eggs numbers } \\
\cline { 2 - 3 } & B. carambolae & B. dorsalis \\
\hline Averrhoa carambolae & $173.8+5.9 \mathrm{a}$ & $68.5+2.3 \mathrm{e}$ \\
Mangifera indica & $98.3+3.5 \mathrm{c}$ & $144.8+5.3 \mathrm{~b}$ \\
Psidium guajava & $122.5+3.7 \mathrm{~b}$ & $102.3+4.5 \mathrm{c}$ \\
Eugenia aquae & $42.0+1.1 \mathrm{e}$ & $30.3+0.7 \mathrm{e}$ \\
Eugenia malaccenensis & $69.8+1.1 \mathrm{~d}$ & $40.0+0.5 \mathrm{e}$ \\
Carica papayae & $26.0+0.8 \mathrm{f}$ & $180.3+2.1 \mathrm{a}$ \\
\hline
\end{tabular}

Numbers in one column followed by the same letters are no significantly difference based on LSD test in level 5\%.

Table 3. Numbers of pupae, male, and female flies of Bactrocera carambolae in laboratory

\begin{tabular}{|c|c|c|c|}
\hline Fruit host & Number of pupae & $\begin{array}{c}\text { Number of flies } \\
\text { female }\end{array}$ & $\begin{array}{c}\text { Number of flies } \\
\text { male }\end{array}$ \\
\hline Averrhoa carambolae & $49.5+1.3 \mathrm{a}$ & $57.0+0.8 \mathrm{c}$ & $20.0+0.6 b$ \\
\hline Mangifera indica & $24.3+0.8 b$ & $46.3+0.4 \mathrm{~d}$ & $15.0+1.2 \mathrm{c}$ \\
\hline Psidium guajava & $20.5+0.9 c$ & $15.5+0.4 \mathrm{f}$ & $8.8+0.2 \mathrm{~d}$ \\
\hline Eugenia aquae & $11.8+0.4 \mathrm{~d}$ & $22.8+0.9 \mathrm{e}$ & $12.0+0.4 \mathrm{~cd}$ \\
\hline Eugenia malaccenensis & $22.5+0.6 b c$ & $66.8+0.8 b$ & $30.8+1.2 \mathrm{a}$ \\
\hline Carica papayae & $10.5+0.9 \mathrm{~d}$ & $77.3+0.4 \mathrm{a}$ & $30.5+1.8 \mathrm{a}$ \\
\hline
\end{tabular}

Numbers in one column followed by the same letters are no significantly difference based on LSD test in level $5 \%$. 
Table 4. Numbers of pupae, male, and female flies of Bactrocera dorsalis in laboratory

\begin{tabular}{lccc}
\hline Fruit host & Number of pupae & $\begin{array}{c}\text { Number of flies } \\
\text { female }\end{array}$ & $\begin{array}{c}\text { Number of flies } \\
\text { male }\end{array}$ \\
\hline Averrhoa carambolae & $11.0 \mathrm{e}+0.6 \mathrm{e}$ & $7.3 \mathrm{~d}+0.4 \mathrm{~d}$ & $3.8 \mathrm{~d}+0.2 \mathrm{~d}$ \\
Mangifera indica & $32.3 \mathrm{~b}+0.4 \mathrm{~b}$ & $23.3 \mathrm{~b}+0.4 \mathrm{~b}$ & $9.0 \mathrm{a}+0.4 \mathrm{a}$ \\
Psidium guajava & $14.0 \mathrm{~d}+1.0 \mathrm{~d}$ & $8.8 \mathrm{~cd}+0.8 \mathrm{~cd}$ & $5.3 \mathrm{c}+0.4 \mathrm{c}$ \\
Eugenia aquae & $14.0 \mathrm{~d}+0.4 \mathrm{~d}$ & $7.5 \mathrm{~cd}+0.3 \mathrm{~cd}$ & $6.5 \mathrm{bc}+0.3 \mathrm{bc}$ \\
Eugenia malaccenensis & $16.8 \mathrm{c}+0.8 \mathrm{c}$ & $9.0 \mathrm{c}+0.4 \mathrm{c}$ & $7.8 \mathrm{ab}+0.4 \mathrm{ab}$ \\
Carica papayae & $36.5 \mathrm{a}+0.8 \mathrm{a}$ & $27.5 \mathrm{a}+0.6 \mathrm{ad}$ & $9.0 \mathrm{a}+0.7 \mathrm{a}$ \\
\hline
\end{tabular}

Numbers in one column followed by the same letters are no significantly difference based on LSD test in level $5 \%$.

Table 5. Survivorship of Bactrocera carambolae from pupae to imago on host plant in laboratory

\begin{tabular}{lrccc}
\hline Host fruit & Number of pupae & $\begin{array}{c}\text { Imago emerged from } \\
\text { pupae (flies) }\end{array}$ & $\begin{array}{c}\text { Imago emerged from } \\
\text { pupae (\%) }\end{array}$ & $\begin{array}{c}\text { Period of pupae } \\
\text { (days) }\end{array}$ \\
\hline Averrhoa carambolae & $49.5+0.3 \mathrm{a}$ & $44.8+0.2 \mathrm{~b}$ & $90.4+1.4 \mathrm{a}$ & $7.3+1.3 \mathrm{c}$ \\
Mangifera indica & $24.3+0.8 \mathrm{~b}$ & $38.8+0.4 \mathrm{a}$ & $79.4+35.9 \mathrm{~b}$ & $7.0+0.8 \mathrm{c}$ \\
Psidium guajava & $20.5+0.4 \mathrm{c}$ & $32.3+0.2 \mathrm{bc}$ & $77.2+13.4 \mathrm{~b}$ & $7.8+0.9 \mathrm{abc}$ \\
Eugenia aquae & $11.8+0.4 \mathrm{~d}$ & $25.0+0.2 \mathrm{c}$ & $57.4+11.5 \mathrm{c}$ & $8.3 \mathrm{a}+0.4 \mathrm{ab}$ \\
Eugenia malaccenensis & $22.5+0.4 \mathrm{c}$ & $12.0+0.3 \mathrm{~d}$ & $87.9+4.5 \mathrm{a}$ & $7.5+0.6 \mathrm{c}$ \\
Carica papayae & $10.5 \mathrm{a}+1.5 \mathrm{a}$ & $19.8+0.3 \mathrm{~d}$ & $57.7+0.4 \mathrm{c}$ & $8.5+0.9 \mathrm{ab}$ \\
\hline
\end{tabular}

Numbers in one column followed by the same letters are no significantly difference based on LSD test in level $5 \%$.

Table 6. Survivorship of Bactrocera dorsalis from pupae to imago on host plant in laboratory

\begin{tabular}{lcccc}
\hline Host fruit & Number of pupae & $\begin{array}{c}\text { Imago emerged from } \\
\text { pupae (flies) }\end{array}$ & $\begin{array}{c}\text { Imago emerged from } \\
\text { pupae }(\%)\end{array}$ & $\begin{array}{c}\text { Period of pupae } \\
\text { (days) }\end{array}$ \\
\hline Averrhoa carambolae & $19.0+1.0 \mathrm{~d}$ & $11.0+0.6 \mathrm{e}$ & $57.9+1.6 \mathrm{c}$ & $8.8+0.2 \mathrm{a}$ \\
Mangifera indica & $39.3+0.8 \mathrm{~b}$ & $32.3+0.4 \mathrm{~b}$ & $82.4+2.6 \mathrm{a}$ & $7.3+0.2 \mathrm{~b}$ \\
Psidium guajava & $22.5+0.6 \mathrm{c}$ & $14.0+1.0 \mathrm{~d}$ & $62.1+3.5 \mathrm{~d}$ & $8.5+0.3 \mathrm{a}$ \\
Eugenia aquae & $19.5+0.6 \mathrm{~d}$ & $14.0+0.4 \mathrm{~d}$ & $72.0+2.3 \mathrm{~d}$ & $8.8+0.2 \mathrm{a}$ \\
Eugenia malaccenensis & $23.0+0.4 \mathrm{c}$ & $16.8+0.8 \mathrm{c}$ & $73.0+4.1 \mathrm{c}$ & $8.5+0.3 \mathrm{a}$ \\
Carica papayae & $42.5+1.1 \mathrm{a}$ & $36.5+0.8 \mathrm{a}$ & $86.0+1.5 \mathrm{a}$ & $7.3+0.2 \mathrm{~b}$ \\
\hline
\end{tabular}

Numbers in one column followed by the same letters are no significantly difference based on LSD test in level $5 \%$.

species. The results of our experimental treatment conducted in our "jar within a jar" apparatus with fans, showed that adult wild-collected $B$. carambolae were most attracted to star fruit and $B$. dorsalis to papaya fruit. Past research confirms that fruit fly host preference for oviposition is primarily affected by the color, smell, taste, and texture of the fruit (Shelly 2000; Shelly \& Kaneshiro 1991), as well as the nutritive value of the fruit, to serve as a source of energy and sustenance for fruit flies throughout their development toward adulthood (Alies 2005). Insects encountering a host for the first time will be affected by these factors as well as the underlying chemical properties expressed via such properties and will select their preference on this basis (Koyama et al. 2004; Akol et al. 2013). Initial attraction to a host fruit seems to directly result in oviposition, as our data showed that numbers of fruit flies entering into the host fruit jars, correlated to the number of ovipositor injections on the fruit in question.

\section{Fecundity and number as well as percentage of pupa successfully emerging as adult fruit flies}

The number of $B$. carambolae ovipositor injections on star fruit, and $B$. dorsalis injections on california papaya, were higher compared to all the other host species (mango manalagi, guava getas merah, E. malaccensis jamaica, and E. aquae citra). Observations showed a correlation between the number of ovipositor injections and the number of eggs laid. This suggests that the star fruit and papaya fruit provided were most suitable places for laying eggs for B. carambolae and B. dorsalis. $B$. carambolae demonstrated highest fecundity with star fruit and guava, laying on average 
number 173.0 eggs and 122.5 eggs, respectively; whereas fecundity was lowest (26.0 eggs) for papaya. The average number of eggs deposited by $B$. dorsalis was highest on papaya and on mango numbering 180.3 and 144.8 , respectively; whereas it was lowest at 30.3 eggs on E. aquae. Star fruit and papaya are known to be especially prone to infestation by fruit flies. These fruit also have a large surface area, soft skin texture, and complete nutrition contents, which might account for why they are preferred by fruit flies B. carambolae and $B$. dorsalis as media to lay eggs. As reported by Fontellas \& Zucoloto (2004), fruit fly ovipositon depends on finding a fruit host suitable for egg inoculation and for nutritional support of the growing offspring (Fontellas \& Zucoloto 2004). Alies (2005) found indications that larger fruit with an attractive smell, color, and shape are more easily infested by fruit flies, while another factor influencing insect oviposition host preference is the local availability of different hosts (Chua 1994; Rauf et al. 2013). Fruit plants that are present in greater numbers or density in a certain location will naturally be more likely to be visited by fruit flies; while fruit plants that are sparsely represented in an area may only rarely be encountered by fruit flies.

Fertilized eggs inoculated in host fruits will hatch into larvae, then develop into pupa. Our research results showed high survival rates for pupae such that the number of eggs correlates roughly to a proportional number of pupa. However, these results were not statistically significant. The highest average number of $B$. caramboae pupae were observed on star fruit and mango fruit at 49.5 pupae and 24.3 pupae respectively; whereas it was lowest, at 10.5 pupae, on papaya. The highest average number of $B$. dorsalis pupae was observed on papaya and mango, numbering 42.5 pupae and 39.3 pupae, respectively; and was lowest, at 19.0 pupae, on star fruit. The highest proportion of $B$. carambolae pupae who successfully reached the imago stage (adulthood) occurred on star fruit and mango fruit at rates of $90.4 \%$ and $79.4 \%$, respectively; and the lowest proportion was $57.4 \%$ for pupae hosted on E. aquae. The proportion of $B$. dorsalis pupae to successfully reach adulthood was highest for those hosted on papaya and mango fruit, with survival rates of $86.0 \%$ and $82.4 \%$, respectively; and was lowest, at $62.1 \%$, on guava (Table 6). Fruit hosts must serve all life stages of the fruit fly in order for the maximum number of eggs to survive to adulthood. Different hosts maybe be suited to one life stage but not others. Therefore we observed the survival rates of fruit flies across each life stage, from oviposition, larval transition into pupae, and successful survival of pupae to imago/adult stage. At each of these stages, a host fruit may prove to be more or less suitable as a host (as reflected by survival rates to the next phase). These results show a consistent correlation between the number of laid eggs, of fully formed pupae and of successfully emerging imago adults which suggests that fruit generally suitable or unsuitable for all phases of development. B. carambolae and B. dorsalis each demonstrated clear-but different--preferences for host fruit species as sites for oviposition.

Different factors may affect fruit fly preferences for host plants, and the ability of selected plants to support fruit fly development through adulthood. Physical characteristics and chemical composition may influence insect preference for certain plants as hosts, and affect the development and biology of fruit flies in their host (Kostal 1993). These characteristics may influence insect behavior in the following ways (Dhillon et al. 2005). Plant compounds can affect the spread of fruit fly, mating location, until oviposition. Papadopoulos et al. (2006), explained that male accessory gland fluids contain compounds responsible for the noted change of behavior. As insects interact differently with fruit hosts based on a variety of ecological, physical and chemical factors, there may be a high level of specificity in choice of host plant by insect species, in favor of specific plants that are uniquely suited to support the development and regeneration of their offspring (Singer 1986; Renwick 1989; Drew et al. 2008).

\section{Period of pupae and sex ratio}

During the pupal stage, we observed no signficant difference in survival rates of pupae raised on different host plants, for either $B$. carambolae or B. dorsalis. Survival rates from pupa to imago were similar on all host species, for both fruit fly species. Generally, during the pupal stage, development is primarily influenced by 
ambient temperature (Hollingswort et al. 1997). In this study temperature was controlled and set to a standard level in the laboratory, so that pupae for all study populations were exposed to identical ambient temperature. Gupta \& Verma (1995) found that that the pupal stage for Bactrocera (Dacus) cucurbitae raised in cucumber ranged between 7.7-9.4 days duration, and 7.0-7.2 days for pupae raised in pumpkin fruit.

During this study $B$. carambolae and $B$. dorsalis produced a greater proportion of female than male progeny, regardless of which host plant was selected (star fruit, mango, guava, $E$. malaccensis, E. aquae, and papaya). This has been observed in prior research on Bactrocera cucurbitae species as well, with infestations of cucumber plants (Prokopy et al. 2003) and melon (Barry et al. 2006). In these studies the population of female fruit fly progeny was larger than the male population, with a sex ratio on C. papaya of $1: 3$ and of $1: 2.5$ for M. indica (Table 4).

Insect selection of hosts for food or reproduction is often influenced by the effect of light or chemical signals on the insect nervous system. As suggested by Schoonhoven et al. (2005), longterm evolution of the chemosensory system can affect the sensitivity of fruit flies species to sensory signals found in their host. Higher preference of B. carambolae in star fruit and was $B$. dorsalis in papaya showed that star fruit and papaya are each important host plant of $B$. carambolae and $B$. dorsalis. Based of older literature, some of host plants species such as guava, E. aqua, star fruit, and papaya found infested by $B$. carambolae and B. dorsalis (Allwood et al. 1999).

\section{CONCLUSION}

Fruit fly B. carambolae showed a host preference for star fruit and mango while $B$. dorsalis preferred papaya and mango fruit for propagation. Mango fruits were the second most- preferred fruit for both B. carambolae and B. dorsalis. Although our findings indicated clear host fruit preferences by each of the studied fruit fly species, it should be noted that laboratory conditions do not reflect conditions in nature, and so do not take into account biotic and abiotic environmental factors, such as the suppression of fruit fly populations by natural enemies, or climatic conditions.

\section{ACKNOWLEDGEMENTS}

I would like thank the head and entire staff of the Entomology Laboratory at the Indonesian Center for Agriculture Biotechnology and Genetic Resource Research, and also the Development and Entomology Laboratory, Division of Zoology, Indonesian Institute of Sciences.

\section{REFERENCES}

Akol AM, Masembe C, Isabirye BE, Kukiriza CK, Rwomushana I. 2013. Oviposition preference and offspring performance in phytophagous fruit flies (Dipter: Tephritidae): The African Invader, Bactrocera invedens. Internation Research Journal of Horticulture 1:1-14. doi: https://doi. org/10.12966/irjh.05.01.2013.

Allwood AJ, Chinajariyawoong A, Drew RAI, Hamacecek EL, Hancock DL. 1999. Host plant record for fruit flies (Diptera: Trphritidae) in South Asia. The Raffles Bulletin of Zoology 7:1-92. Aluja M, Hurtado HC, Liedo P, Cabrera M, Castillo F, Guillen J, Rios E. 1996. Seasonal population fluctuation and ecological implication for management of Anastrepha fruit flies (Diptera: Tephritidae) in commercial mango orchard in Southern Mexico. Journal of Economic Entomology 89:654-667. doi: https://doi. org/10.1093/jee/89.3.654.

Barry DJ, Miller NW, Pinero JC, Tuttle A, Ronald F, Mau L, Vargas RI. 2006. Effectiveness of protein baits on melon fly and oriental fruit fly (Diptera: Tephritidae): attraction and feeding. Journal of Economic Entomology 99:1161-1167. doi: https://doi.org/10.1093/jee/99.4.1161.

Chang HY, Tzeng CC, Tsai WH, Kao SS, Tseng YH. 2003. Phylogenetic study of the Dacinae (Dipetra; Tephritidae) using partial sequences of mitochondrial 16S ribosomal DNA. Plant Protection Bulletin Taipei 45:1-15.

Chua TH. 1994. Egg batch size of the Carambolae fruit fly, Bactrocera sp. (Malaysian A) (Diptera: Tephritidae). Pertanika Journal of Tropical Agricultural Science 17:107-109.

Clarke AR, Amstrong KF, Charmichael AE, Milne JR, Raghu S, Roderick GK, Yeates DK. 2005. Invasive 
phytophagous pest arising through a recent tropical evolutionary radiation: the Bactrocera dorsalis complex of fruit flies. Annual Review of Entomology 50:293-319. doi: https://doi. org/10.1146/annurev.ento.50.071803.130428.

Dhillon MK, Singh R, Naresh JS, Sharma HC. 2005. The melon fruit fly, Bactrocera cucurbitae: a review of its biology and management. Journal of Insect Science 5:40-45. doi: https://doi. org/10.1093/jis/5.1.40.

Drew RAI. 1997. The economic and social impact of the Bactrocera papayae Drew and Hancock (Asian papaya fruit fly) outbreak in Australia. In: Allwood AJ, Drew RAI (Eds.), Symposium on Management of Fruit Flies in the Pacific. Proceeding of Australian Country industrial Research (Nadi, Fiji 28-31 October 1996). pp. 205-207. Canberra: Australian Centre for International Agricultural Research.

Drew RAI, Rodgers Dj, Vijaysegaran S, Moore CJ. 2008. Mating activity of Bractocerra cacuminata (Hering) (Diptera: Tephritidae) on its larval host plant Solanum mauritianum Scopoli in Southeast Queensland. Bulletin of Entomological Research 98:77-81. doi: https:// doi.org/10.1017/S0007485307005408.

Fletcher BS. 1987. The biology of dacine fruit flies. Annual Review of Entomology 32:11544. doi: https://doi.org/10.1146/annurev. en.32.010187.000555.

Fontellas-Brandalha TML, Zucoloto FS. 2004. Selection of oviposition sites by wild Anastrepha obliqua (Macquart) (Diptera: Tephritidae) based on nutritional composition. Neotropical Entomology 33:557-562. doi: https://doi. org/10.1590/S1519-566X2004000500003.

Gupta D, Verma AK. 1995. Host specific demographic studies of the melon fruit fly, Dacus cucurbitae Coquillett (Diptera: Tephritidae). Journal of Insect Science 8:87-89.

Han HY, McPheron BA. 1997. Molecularp hylogenetic study of Tephritidae (Insecta: Diptera) using partial sequences of the mitochondrial $16 \mathrm{~S}$ ribosomal DNA. Molecular Phylogenetics and Evolution 7:17-32. doi: https://doi.org/10.1006/ mpev.1996.0370.

Hardy DE. 1977. Famili Tephritidae. In: Delfinado MD, Hardy DE (Eds.), A catalog of the Diptera of the Orriental Region. pp. 3:44-134. Hawai: Univ. Hawaii Press.

Hasyim A, Muryati, de Kogel WJ. 2006. Efektivitas model dan ketinggian perangkap dalam menangkap hama lalat buah jantan, Bactrocera spp. Jurnal Hortikultura 16:314-320.
Hollingsworth RM, Vagalo M, Tsatsia F. 1997. Biology of melon fruit fly, with speciel reference to the Solomon Island. In: Allwood AJ, Drew RAI (Eds.), Symposium on Management of fruit flies in the Pacific. Proceeding of Australian Country industrial Research (Nadi, Fiji 28-31 October 1996). pp. 140-144. Canberra: Australian Centre for International Agricultural Research.

Kostal V. 1993. Physical and chemical factors influencing landing and oviposition by the cabbage root fly on host-plant models. Entomologia Experimentalis et Applicata 66:109-118. doi: https://doi.org/10.1111/j.1570-7458.1993. tb00698.x.

Koyama J, Kakinohana H, Miyatake T. 2004. Eradication of the melon fly, bactrocerra cucurbitae, in Japan: importance of behavior, ecology, genetics ad evolution. Annual Review of Entomology 49:331-349. doi: https://doi. org/10.1146/annurev.ento.49.061802.123224.

Meats A, Holmes HM, Kelly GL. 2004. Laboratory adaptation of Bactrocera tryoni (Diptera: Tephritidae) decreases mating age and increases protein consumption and number of eggs produced per milligram of protein. Bulletin of Entomological Research 94:517-524. doi: https://doi.org/10.1079/BER2004332.

Nasution IA, Kuswadi AN. 2004. Perendaman telur, penggunaan suhu rendah dan aerasi untuk perbaikan pembiakan massal lalat buah Bactrocera carambolae (Drew \& Hancock) dalam teknik serangga mandul. In: Risalah Seminar ilmiah Penelitian dan Pengembangan Aplikasi Isotop dan Radiasi, Pertanian, Peternakan, Industri, Hidrology dan Lingkungan. hlm. 123128. Jakarta: Puslitbang Teknologi Isotop dan Radiasi.

Papadopoulos NT, Kouloussis NA, Katsoyannos BI. 2006. Effect of plant chemicals on the behavior of the mediterranean fruit fly. In: Fruit Flies of Economic Importance: From Basic to Applied Knowledge Proceedings of the 7th International Symposium on Fruit Flies of Economic Importance (Salvador, 10-15 September 2006), pp. 97-106. Salvador: International Symposium on Fruit Flies of Economic Importance.

Plant Health Australia. 2016. Australian Handbook for the Identification of Fruit Flies. Canberra: Australian Government, Department of Agriculture and Water Resource.

Prokopy JR, Miller NW, Pinero JC, Barry JD, Tran LC, Oride I, Vargas RI. 2003. Effectiveness of GF-120 fruit fly bait spray applied to border area plants for control of melon flies (Diptera: 
Tephritidae). Journal of Economic Entomology 96:1485-1493. doi: https://doi.org/10.1093/ jee/96.5.1485.

Rauf I, Ahmad N, Masoom SM, Rashdi S, Ismail M, Khan MH. 2013. Laboratory studies on ovipositional preference of the peach fruit fly Bactrocera zonata (Saunders) (Diptera: Tephritidae) for different host fruits. African Journal of. Agricultural Research 8:1300-1303. doi: https://doi.org/10.5897/AJAR2013.6744.

Renwick JAA. 1989. Chemical ecology of oviposition in phytophagous insects. Experientia 45:223228. doi: https://doi.org/10.1007/BF01951807.

Resilva S, Obra G, Zamora N, Gaitan E. 2007. Development of quality control procedures for mass produced and released Bactrocera phillipinensis for sterile insect technique programs. Florida Entomologist 90:58-63. doi: https://doi.org/10.1653/0015-4040(2007)90[58:DO QCPF]2.0.CO;2.

Sarwono. 2000. PHT lalat buah Bactrocera dorsalis pada mangga. Buletin Teknologi dan Informasi Pertanian 6:142-149.

Schoonhoven LM, van Loon JJA, Dicke M. 2005. Insect-plant Biology. New York: Oxford University Press.

Singer MC. 1986. The definition and measurement of oviposition preference in plant-feeding insect. In: Miller JR, Miller TA, (Ed). Insect-plant interactions. pp. 66-94. New York: SpringerVerlag. doi: https://doi.org/10.1007/978-1-46124910-8_3.

Siwi SS, Hidayat P, Suputa. 2006. Taksonomi dan Bioekologi Lalat Buah Penting di Indonesia (Diptera: Tephritidae). Bogor: Balitbang Bioteknologi dan Sumberdaya Genetik Pertanian dengan Departement of Agriculture, Fisheries and Forestry Australia.
Shelly TE. 2000. Flower-feeding effects mating performance in male oriental fruit flies, Bactrocera dorsalis. Ecological Entomology 25:109-14. doi: https://doi.org/10.1046/j.13652311.2000.00231.x

Shelly TE, Kaneshiro KY. 1991. Lek behavior of the oriental fruit fly in Hawaii. Journal of Insect Behavior 4:235-41. doi: https://doi.org/10.1007/ BF01054615.

Sikumbang, D. 2005. Perbaikan teknik perbanyakan lalat buah (Bactrocera carambolae Drew and Hancock) untuk menunjang program pengendalian hama dengan teknik serangga mandul. In: Sutrisno S. et al. (Ed.), Risalah Seminar Ilmiah Penelitian dan Pengembangan Aplikasi Isotop dan Radiasi. hlm. 269-273 Jakarta: Badan TenagaAtom Nasional. Puslitbang Teknologi Isotop dan Radiasi. Jakarta.

Vargas RI, Walsh WA, Kanehisa D, Stark JD, Nishida T. 2000. Comparative demography of three Hawaiian fruit flies (Diptera: Tephritidae) at alternating temperatures. Ecology and Population Biology 93:75-81. doi: https://doi. org/10.1603/0013-8746(2000)093[0075:CDOT $\mathrm{HF}] 2.0 . \mathrm{CO} ; 2$.

Widayana R, Kuswadi AN. 2006. Pengaruh iradiasi gamma terhadap kemampuan kawin dan fertilitas lalat buah Bactrocera carambolae (Drew \& Hancock). In: Pattiradjawane EL et al. (Eds.), Risalah Seminar ilmiah Aplikasi Isotop dan Radiasi (Jakarta, 12 Desember 2006). hlm. 107-112. Jakarta: Badan tenaga Nuklir Nasional. Jakarta.

White IM, Harris ME. 1992. Fruit Flies of Economic Significance: Their Identification and Bionomics. London: C.A.B International-ACIAR. 